\title{
PSYCHE
}

\begin{tabular}{lll}
\hline Vol. 59 & March, 1952 & No. 1
\end{tabular}

\section{SIX NEW SPECIES OF MEGISTOPS \\ WITH KEYS TO THE KNOWN SPECIES \\ (COLEOPTERA)*}

\section{By DoRIS H. Blake \\ Arlington, Virginia}

The genus Megistops, originally based by Boheman ${ }^{1}$ on two species supposedly from San Francisco but actually from Ecuador ${ }^{2}$, at present contains fifteen species. Eight of these were described from the West Indies, ranging from Cuba to Trinidad, and the other seven from Venezuela (1), Brazil (3), Ecuador (2), and Paraguay (1). The group is for the most part fairly homogeneous in its size, shape and coloring, being composed of small $(2-5 \mathrm{~mm}$.), oval beetles with extraordinarily large eyes that in some are contiguous on the occiput. Eight of the species (three from the West Indies) have deep reddish brown or piceous elytra with four large pale spots, five have dark spots on pale yellow elytra, and four (from the West Indies) have streaks or subvittate dark markings. Only five (of which three, I believe, are merely dark color forms of other species) have the elytra of one color. It is not difficult to conceive that all of these color patterns on the elytra are degrees of coloring of the typical four-spotted elytra, varying from nearly pale, with only remnants of spots, to entirely dark.

Recently I have been able to examine many type specimens of Boheman's, Baly's, Jacoby's, Bryant's, and Duvi-

* Published with a grant from the Museum of Comparative Zoology at Harvard College.

${ }^{1}$ Boheman, Eugenia Resa, Coleoptera, 1859, p.187.

2 Blake, Bull. Brooklyn Ent. Soc., vol. 26, 1931, p.8. 
vier's species. Since I have six more to add to the genus and since they comprise two from the West Indies, three from South America and the first one to be described from the mainland of North America (Costa Rica), it seems worth while to give keys to both the West Indian and South American species.

\section{Key to West Indian Species}

1. Pale yellow except for the dark antennae and dark streaks on legs. Cuba ............. adulta Suff. Elytra with spots or vittae or entirely dark ..... 2

2. Elytra entirely dark ............... 3 Elytra not entirely dark .............. 5

3. Elytra deep blue, eyes not very close together, Puerto Rico ... . . . . . . . . . . . . . . . . . dissita Blake

Elytra piceous or reddish brown . . . . . . . . 4

4. Elytra piceous black. Cuba ..... rubropustulata Suff. Elytra deep reddish brown. Puerto Rico tabebuiae Blake

5. Elytra dark with 4 pale spots $\ldots \ldots \ldots \ldots \ldots \ldots 6$

Elytra not with 4 pale spots $\ldots \ldots \ldots \ldots \ldots \ldots$

6. Elytral pale spots elliptical. Trinidad

trinitatis Bryant Elytral pale spots more or less irregular in shape . . . 7

7. Basal pale spot not running parallel to suture but curving away from it towards margin. Harbor Island, Bahamas ........... bahamensis $\mathrm{n}$. $\mathrm{sp}$.

Basal pale spot running parallel to suture, sometimes coalescing with apical spot. Puerto Rico

tabebuiae Blake

8. Elytra pale with 2 dark triangular spots on each in the middle and a dark lateral stripe. Grenada

granulata Jacoby

Elytra black, yellow brown or reddish brown with streaks or lines $\ldots \ldots \ldots \ldots \ldots \ldots \ldots \ldots$ 
9. Elytra black with 6 red streaks ("litura"). Cuba rubropustulata Suff. Elytra reddish brown or yellowish brown with streaks ..................... 10

10. Elytra reddish brown with pale base and pale streaks down towards the middle and vestiges of other streaks in apical half. Puerto Rico .... fictor Weise

Elytra yellow brown with dark brown narrow vittae ...................... 11

11. Elytra with heavy black margin joining at middle with a median dark vitta, a sutural vitta and a subsutural vitta often uniting, neither of these median vittae entire. Puerto Rico ............ bryanti n. sp.

Elytra with a narrow sutural and 3 short median vittae and also dark markings on the humeri and along the margin and near apex. Santo Domingo.

liturata Olivier

Key to South American Species

1. Elytra dark, without spots. Ecuador

lugubrina Boheman ${ }^{3}$

Elytra spotted ................... 2

2. Elytra dark with pale spots $\ldots \ldots \ldots \ldots \ldots \ldots 3$

Elytra pale with darker spots . . . . . . . . 8

3. Elytra 10-spotted. Paraguay ... 10-maculata Bryant Elytra 4 -spotted .................. 4

4. Large (nearly $5 \mathrm{~mm}$.), oblong, thorax with a median dark vitta, spur at apex of hind tibiae very short and broad. Brazil ............. fenestrata Illiger

Smaller (2-4 mm.), thorax without a median vitta, spurs on the hind tibiae of the usual length ..... 5

5. The pale basal spot on each elytron curved about from base near scutellum towards margin. Ecuador

4-notata Boheman

${ }^{3}$ Probably dark form of 4-notata Boheman. 
The pale basal spot on each elytron not noticeably curved towards margin ...............6

6. Beetle elongate oval with elongate basal spot. Venezuela ..................... pretiosa Baly

Beetles more oval, less elongate . . . . . . . . . 7

7. About $2.5 \mathrm{~mm}$. in length, elytral basal spot oblong. Amazon, Brazil ............... ornata Baly

About $3.5 \mathrm{~mm}$. in length, elytral basal spot elliptical and extending obliquely towards margin. Trini-

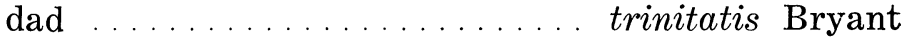

8. Elytra pale orange yellow, 4 dark spots, the suture and apex dark, lateral margin pale. Brazil vandepolli Duvivier

Elytra pale with 4 dark spots or vittae, lateral margin more or less darkened

9. Each elytron with an angular spot in the middle, sometimes one at middle of the base, the suture pale. Grenada granulata Jacoby

Suture dark in part or entirely dark

10. A large median dark spot common to both elytra, otherwise suture pale. South America .... taurops n. sp. Suture dark from base to apex ............ 11

11. Body beneath, femora and tibiae in part dark. Bolivia ................. melanoloma n. sp.

Body beneath, femora and legs pale yellow brown. Argentina argentinensis n. sp.

Megistops bryanti n. sp.

(Plate 1, figure 8)

About $3.5 \mathrm{~mm}$. in length, smooth, oval, faintly shining, pale yellow brown, the elytra with dark brown sutural and lateral margins, covering humeri and wider at apex, and a long but not entire subsutural vitta often connecting with the sutural vitta, and a shorter median vitta connecting with the lateral marginal one below middle; breast and often middle of prosternum deeper brown. 
Head pale yellow brown with dark mouthparts, eyes almost meeting on occiput. Antennae brownish, the three basal joints paler beneath. Prothorax not quite twice so broad as long, narrowed anteriorly and with thickened apical angles; pale yellow, in some specimens, with faint traces of five spots, faintly and shallowly punctate. Elytra rather flat, feebly shining and finely alutaceous with obsolete fine punctures; pale yellow brown with deeper brown markings in the shape of a sutural vitta often uniting with a shorter subsutural one, and also with the wide irregular lateral-marginal one before the apex, another even shorter median vitta uniting a little below the middle with the lateral marginal darkening. Body beneath often deeper brown except the pale abdomen and legs; in dark specimens apical half of hind femora deep brown. Length $3-3.7 \mathrm{~mm}$; width $1.5-1.8 \mathrm{~mm}$.

Type data.-Holotype male and 28 paratypes (U.S.N.M. Cat. No. 60,930), 2 paratypes in M.C.Z. (No. 28,691), all collected by R. G. Oakley on Tabebuia sp. June 25, 1934, at Guanica, Puerto Rico.

Other material.-In U.S.N.M. collected by R. G. Oakley on Tabebuia sp. Oct. 4, 1933, and on Scirpus validus Sept. 29, 1933, both at Ponce, and on Clusia rosea by Martorell April 2, 1940, near Rio Piedras; in M.C.Z. one specimen collected by C. M. Matos at Guanica in the Stuart T. Danforth collection.

Remarks.-At first the beetles would seem to be a more heavily marked race of $M$. liturata Oliv., a species occurring in Hispaniola, but dissection reveals an entirely differently shaped aedeagus. $M$. liturata also appears to be a little broader with more granular surface. $M$. tabebuiae from Puerto Rico also feeds on Tabebuia but the two beetles are not at all alike either in their external appearance or in their aedeagi, M. tabebuiae usually being dark reddish brown to piceous, sometimes with four pale elytral spots or, in pale specimens, with the spots coalescing. The species is dedicated to G. E. Bryant of the British Museum, who has done much work on the genus. 


\title{
Megistops bahamensis n. sp.
}

\author{
(Plate 1, figure 6)
}

About $3.5 \mathrm{~mm}$. in length, oval, feebly shining, alutaceous and finely punctate, deep reddish brown with pale yellow prothorax and the elytra with four large pale yellow spots somewhat irregular in shape, the two basal ones being longer than the apical ones.

Head yellow brown with darker mouthparts, eyes only slightly separated on the occiput. Antennae reddish brown, the basal joints yellowish below. Prothorax twice as wide as long, narrowed anteriorly with thickened apical angles; surface alutaceous and thickly and finely punctate, in some specimens traces of five indistinct spots. Elytra deep chocolate brown to piceous with four pale yellow spots, the basal one on each elytron being larger and curving irregularly towards the lateral margin, the apical one smaller and usually more rounded. Body beneath usually with the middle of the prosternum and breast and apical half of hind femora deeper brown. Length 3.4-3.7 mm.; width $1.9 \mathrm{~mm}$.

Type data.-Holotype male (U.S.N.M. Cat. No. 60,931) and 6 paratypes, 3 paratypes in M.C.Z. (Type No. 28,690), all collected on Harbor Island, Bahamas, July 8 by H. F. Wickham.

Remarks.-The only West Indian species likely to be confused with this is one of the color forms of M. tabebuiae Blake, in which one specimen with deep brown elytra has very faint traces of four small spots and another specimen has the spots so large as to coalesce leaving only the suture and margin dark. These two species have rather similarly shaped but clearly different aedeagi, that of the Bahaman species having a wider, more rounded tip.

Explanatic N of Plate 1

Fig. 1. Megistops costaricensis n. sp. Fig. 2. Megistops melanoloma n. sp. Fig. 3. Megistops vandepolli Duv. Fig. 4. Megistops argentinensis n. sp. Fig. 5. Megistops taurops n. sp. Fig. 6. Megistops bahamensis n sp. Fig. 7. Megistops liturata (Oliv.) Fig. 8. Megistops bryanti n. sp. 


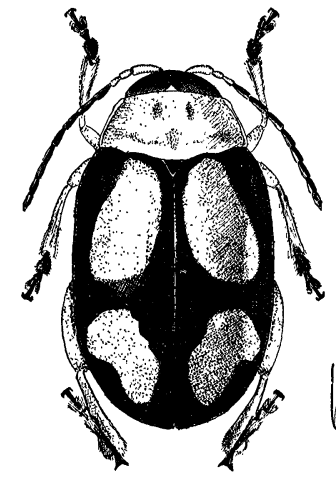

1. Meơistops costaricensis

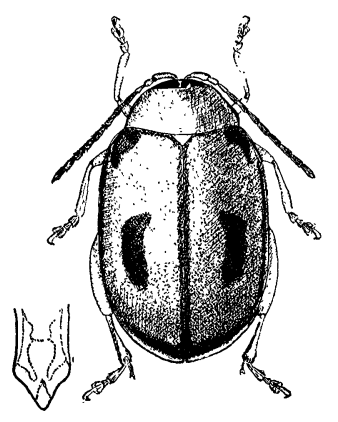

4. Meçistops arq̨entinensis vittate form?

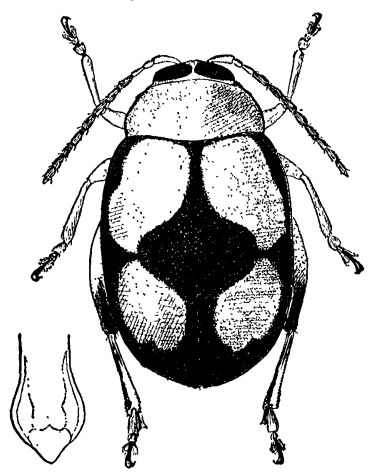

6. Meçistops bahamensis.

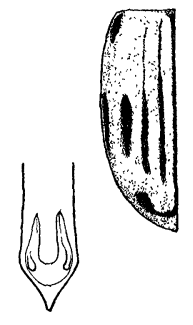

7. Meg̨istops liturata (Oliv.)

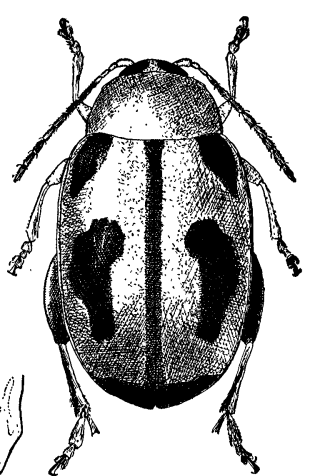

2. Mcogistops melanoloma
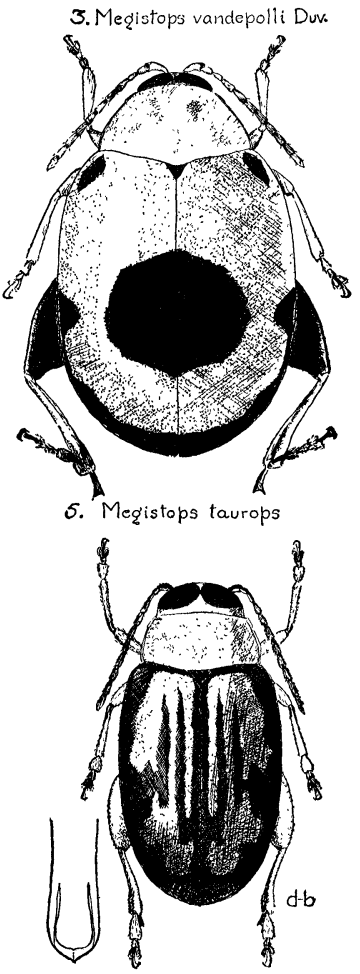

8. Megistops bryantt

BlaKe - MEgISTOPS 
Megistops melanoloma n. sp.

(Plate 1, figure 2)

Between 3 and $3.5 \mathrm{~mm}$. in length, oval, feebly shining, head, undersurface, femora and part of tibiae dark, prothorax pale orange yellow, elytra also pale with a black sutural and lateral marginal vitta, a black spot on humerus and a large median spot common to both elytra.

Head with the eyes very little separated on the occiput, deep brown, very finely and densely punctate. Antennae dark brown with the three basal joints pale yellow. Prothorax at base twice as wide as long, very finely and densely punctate, pale orange, in one specimen with five faint spots. Elytra pale orange, finely and faintly punctate, with black markings on humeri, black sutural vitta, and black lateral marginal vitta widening at apex and joined with sutural dark vitta; in the middle of each elytron an elongate black spot in the form of a short vitta. Body beneath and femora black with deep brown coxae and tibiae streaked with black, tarsal joints deep brown. Length 3.2$3.4 \mathrm{~mm}$.; width $2 \mathrm{~mm}$.

Type data.-Holotype male (U.S.N.M. Cat. No. 60,933), collected in May by G. L. Harrington, at Encuentro, Dept. La Paz, Bolivia.

Other material.-One other specimen also collected by G. L. Harrington, at Calisaya, Rio Bopi, Bolivia.

Remarks.-This species is closely related to $M$. vandepolli Duv. described from Santarem, on the Amazon River, and may be only a race of that species. But because of the wide difference in locality coupled with the slight differences in structure, such as the more closely placed eyes and the more narrowed tip to the aedeagus, as well as the darker coloring of the legs and elytra, I believe this is distinct.

Megistops argentinensis $n$. sp.

(Plate 1, figure 4)

From 2.5-3.5 mm. in length, oval, feebly shining, yellow brown with deeper brown markings on the elytra, a sutural 
vitta uniting broadly near the apex with a narrow lateral marginal vitta, a humeral dark spot and an elongate spot in the middle of each elytron sometimes becoming a vitta that does not extend to the base.

Head pale with deeper brown mouthparts, finely punctate, eyes nearly meeting on the occiput. Antennae pale brownish with the three basal joints yellowish. Prothorax twice as broad as long at base with thickened apical angles, finely and densely punctate, sometimes very faintly 5spotted. Elytra a little more shining, distinctly and rather densely punctate, pale with deeper brown markings in the form of a sutural vitta uniting broadly at apex with a lateral marginal vitta, also a spot on humerus and a median elongate spot, sometimes becoming a short median vitta. Body beneath yellowish or reddish brown with paler tibiae and tarsi. Length 2.6-3.5 mm.; width 1.7-2 mm.

Type data.-Holotype male (U.S.N.M. Cat. No. 60,932), and four paratypes from Tucuman, Argentina, collected Oct. 11, 1925 by G. F. Moznette.

Other material.-In the U.S.N.M.: Argentina: 4 specimens from Santiago del Estero, collected April 13, 1940 by H. L. Parker, 6 specimens from Betania de Salta collected in a citrus grove May 13, 1927 by M. Kisliuk. In M.C.Z. in Bowditch collection: 1 specimen from Tucuman Prov. collected by C. Bruch, 1 from Jujuy, 2 from Catamarca Prov., C. Bruch, all these from Argentina. One specimen in collection F. Monros collected at Tarija on Rio Bermejo, Bolivia, Oct. 20, 1948 by A. Marlinez.

Remarks.-This is another species closely related to $M$. vandepolli Duv., but distinguished by the dark lateral vitta and the slightly differently shaped aedeagus. It is a paler species also, being yellow brown and not orange brown, and has brownish dark markings instead of black. As in the case of $M$. melanoloma, the median elytral spot is more elongate and less triangular, and in some specimens in a series from the same locality the median spot is lengthened to a vitta, which, however, does not extend to the base. So far specimens have been seen only from the northwestern part of Argentina and from Bolivia. 
Megistops taurops n. sp.

(Plate 1, figure 5)

About $4 \mathrm{~mm}$. in length, broadly oval, faintly shining, pale orange yellow above with deep brown to piceous head, undersurface and hind legs; anterior legs with basal half of femora dark; scutellum dark, elytra with a large dark median spot common to both elytra, a spot on the humerus and dark apex with the margin from apex to middle dark.

Head dark, eyes (in female) well separated on the occiput. Antennae with the first four joints pale, rest piceous, second joint fully as long as third, fourth twice as long. Prothorax approximately twice as wide as long at base, narrowed anteriorly and with thickened apical angles; surface not very shiny, granular, pale orange yellow with traces of five spots. Scutellum dark. Elytra granular with the surface sculpture a little smoother than the prothorax and very finely and substriately punctate; pale orange yellow with a piceous spot on the humerus and a large spot common to both elytra slightly below the middle, the apex broadly dark with the margin from the apex to the middle dark and widened into a lobe at the middle. Body beneath with the middle of the prothorax, breast and abdomen dark brown to piceous, hind legs also dark, anterior pairs of legs with the basal half of femora dark but rest paler, tarsi brown. Length $4 \mathrm{~mm}$; width $2.5 \mathrm{~mm}$.

Type data.-Holotype female M.C.Z. Type No. 28,689. No locality label on the specimen but probably from South America.

Remarks.-Although no locality label is on the single female specimen, it is safe to say that this was collected in South America and probably in Brazil or southward. The specimen, which is included in Jacoby's second collection, now in the Bowditch collection, bears a label "Burchell collection". Burchell is known to have collected in South America. The markings on the humerus and apex resemble those of $M$. vandepolli Duv., but the large size and striking large spot on the middle of the elytra make it quite different in appearance. Possibly it is a color form 
of a four-spotted species. It is larger than any four-spotted species except $M$. fenestrata Illiger, which, unlike it, has a median vitta on the prothorax.

Megistops costaricensis n. sp.

$$
\text { (Plate 1, figure 1) }
$$

About $3.5 \mathrm{~mm}$. in length, oval, moderately shiny, finely and densely punctate, pale yellow brown with deeper reddish brown mouthparts, dark outer joints to the antennae, pale brown undersurface and legs, and the elytra deep brown with four pale spots, the basal ones being more elongate and larger.

Head with eyes contiguous, a slightly produced carina extending from lower front with a few scattered punctures on it; mouthparts deeper in color. Antennae with the three basal joints paler than the distal ones, joints 2 and 3 about equal. Prothorax approximately twice as wide as long at base, narrowed apically, pale yellow with five indistinct spots, finely and densely punctate (granular), smoothly rounded but not very convex, and without depressions, basal margin sinuate. Scutellum small, deep brown. Elytra deep brown, almost piceous, each with an elongate pale basal spot curving outwards towards margin and larger than the apical spot, which curves irregularly from the margin to the suture; surface moderately shiny, granular. Body beneath deeper reddish brown, shining. Length 3.7 $\mathrm{mm}$.; width $2 \mathrm{~mm}$.

Type data.-Holotype, female and one paratype, female, U.S.N.M. Cat. No. 61,195. Taken on Lippia berlandieri Schauer, at San Pedro de Montes de Ora, Costa Rica, July 12, 1935, by Sofia Ballou.

Remarks.-This is the first species of Megistops to be taken on the North American continent, the species hitherto being known only from the West Indies and South America. The markings are similar to many other species, notably $M$. pretiosus Baly, from Venezuela, and $M$. trinitatis Bryant from Trinidad. $M$. pretiosus is described as having the thorax three times as broad as long, and Bryant 
describes $M$. trinitatis as being broader than $M$. pretiosus, so $M$. costaricensis is a more slender beetle than either of them.

INTERESTING NORTHERN RECORDS FOR EASTERN HYMENOPTERA (FORMICIDAE AND EmbolemidAe).- On May 3, 1952, a mild, sunny day, Dr. W. L. Nutting, Dr. F. G. Werner and myself spent an afternoon collecting on Horn Pond Hill, near Winchester and Woburn, Massachusetts. This glaciated hill, low and largely denuded of its forest cover, bears many stones loosely set in the soil and providing excellent ant collecting. Under a large stone covering a nest of Formica fusca L., Werner discovered foraging workers of Smithistruma (Wessonistruma) pergandei (Emery) ; the nest of this ant was found under an adjoining rock. We secured most (perhaps $90 \%$ ) of the population, which seemed unusually large for a dacetine nest, and a count yielded a total of 648 workers and 3 females (deälate queens). This is the largest population recorded for the nest of any dacetine species, and is more than twice the usual maximums recorded previously for this and other species. Previous northern records for $S$. pergandei are from nearby Boston and Cambridge, only a few miles farther south.

Beneath the rock covering the $S$. pergandei nest, but to one side, were found three workers of Proceratium silaceum. Roger, of which the northeastern limit has been considered to rest in southern New York.

Under another rock overturned by Werner was found a female of the curious embolemid wasp, Embolemus nearcticus (Brues), previously known from Massachusetts (Stony Brook Reservation) and New York. This specimen is very similar to the types in the Museum of Comparative Zoology, but is darker and more brownish in color. It was found crawling on the under side of the rock. It is interesting to note that all the records for this insect are dated in May. The host is unknown. - W. L. Brown, JR., Museum of Comparative Zoology, Harvard University. 

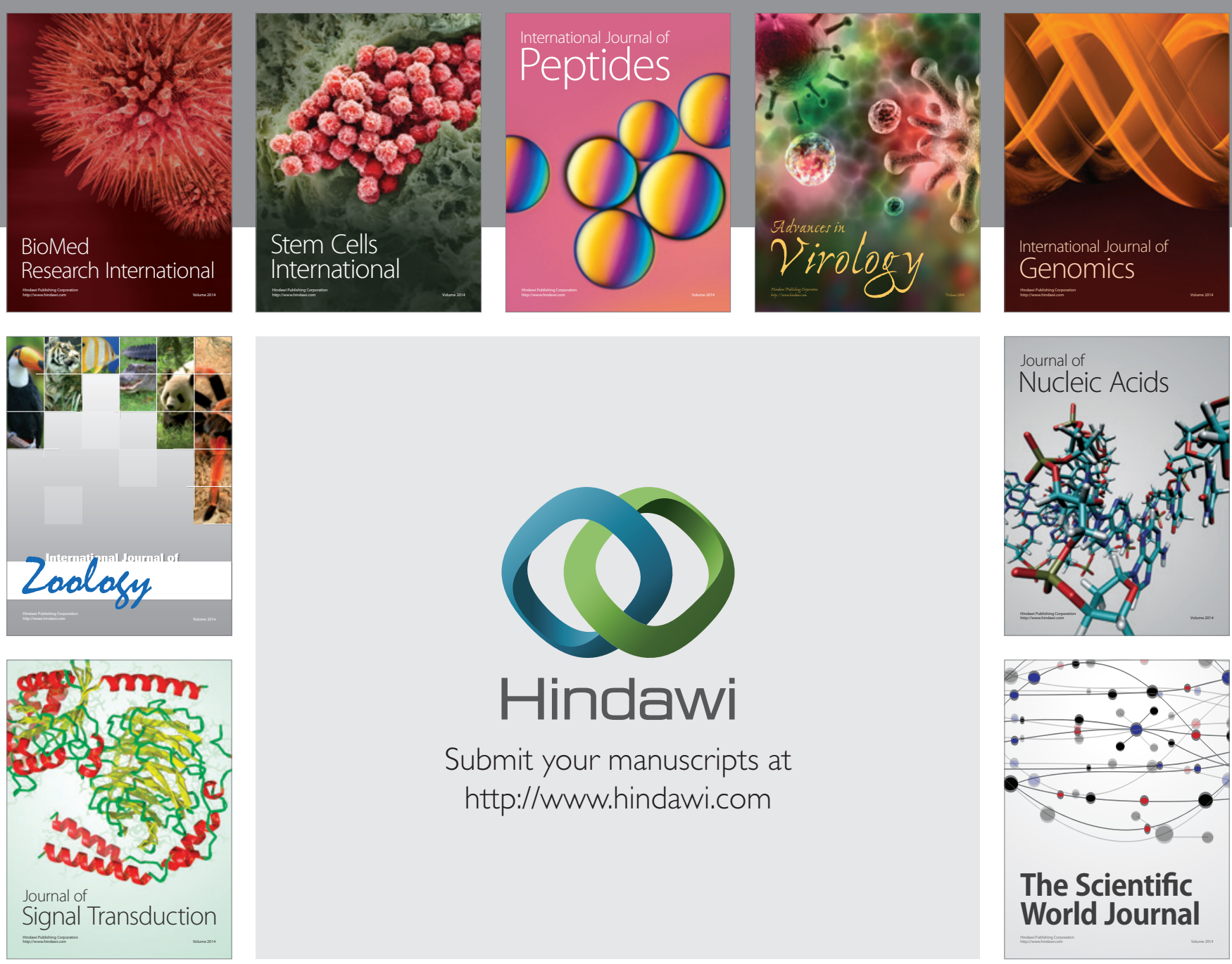

Submit your manuscripts at

http://www.hindawi.com
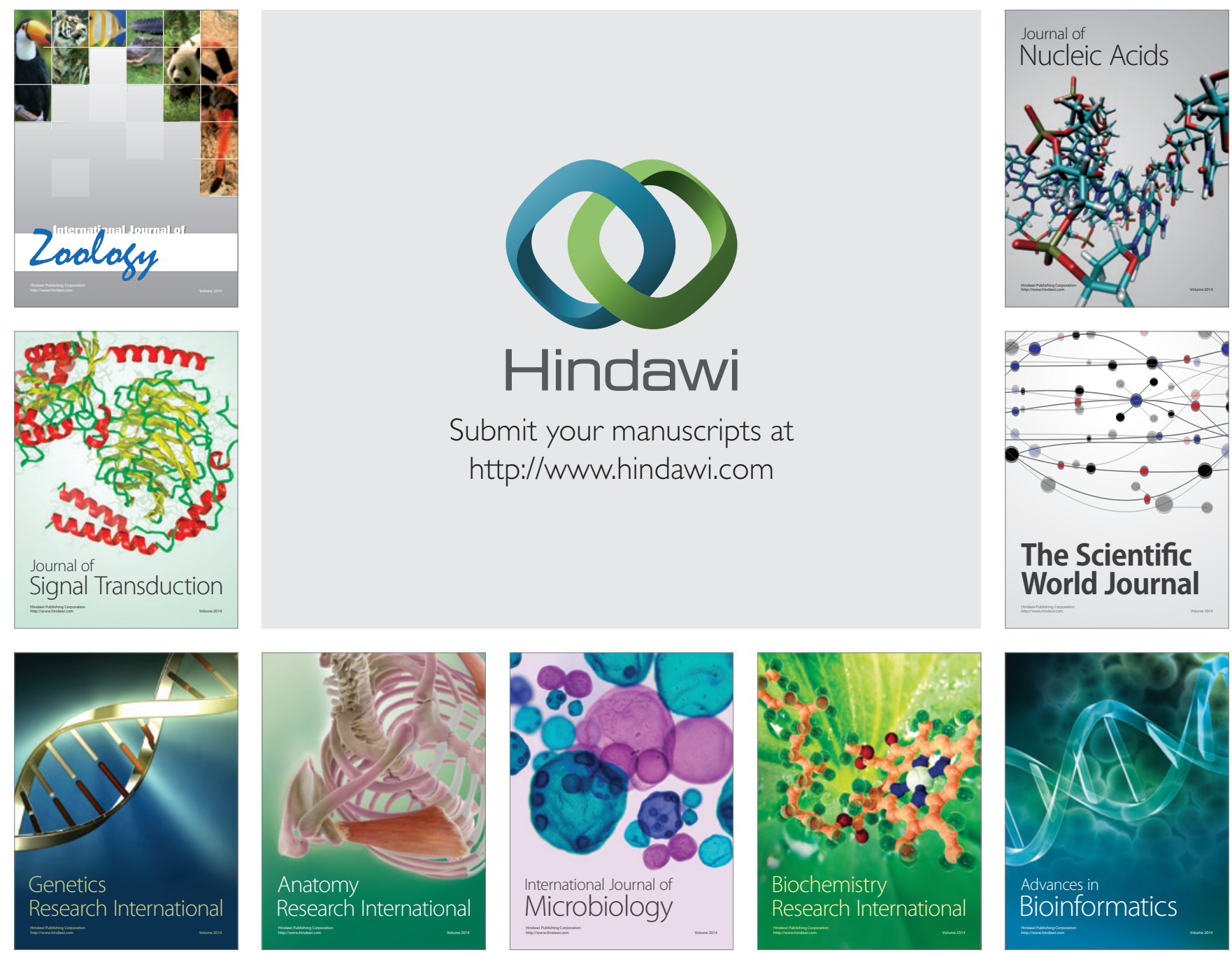

The Scientific World Journal
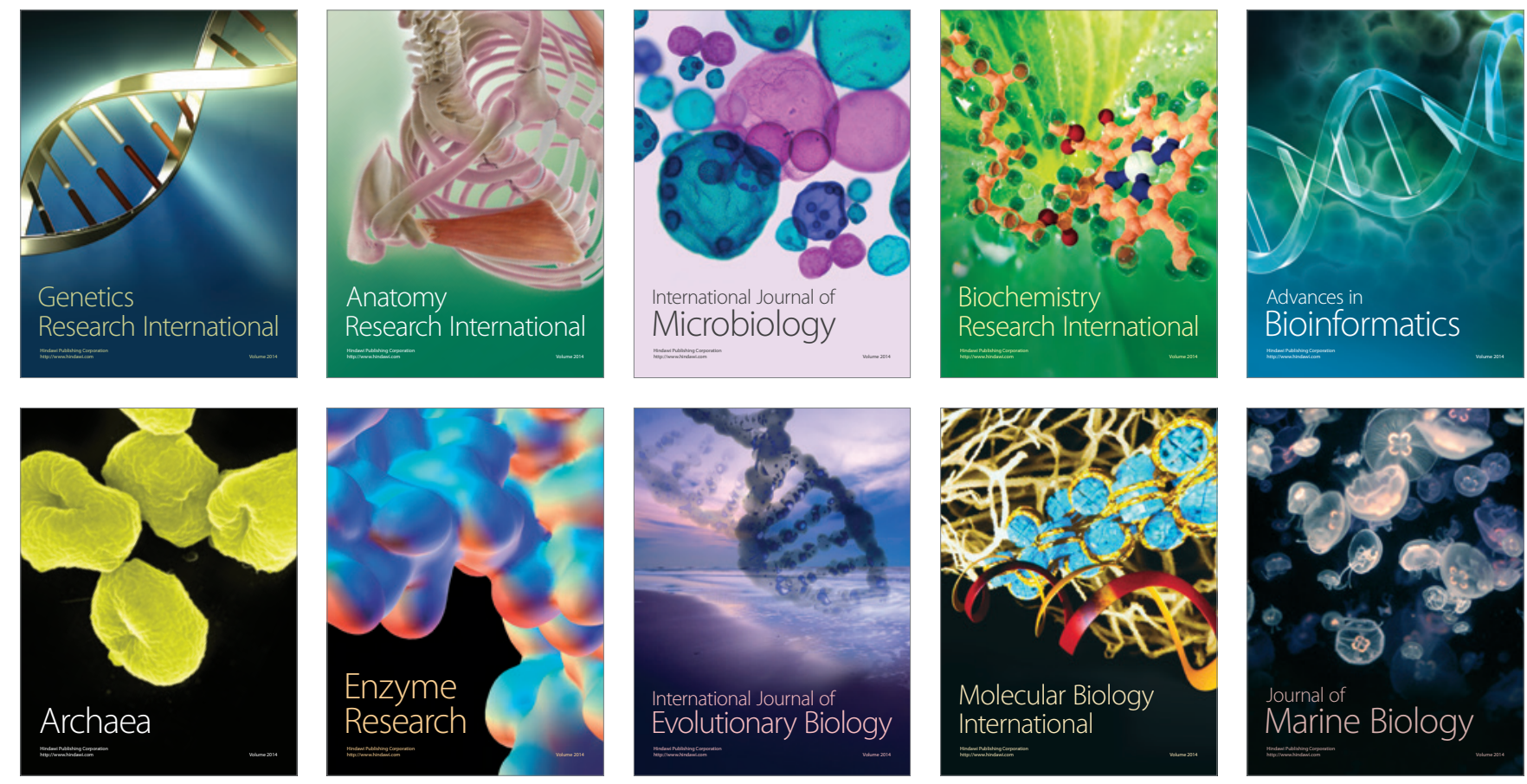